\title{
Středověká hrnčířská pec z Uherského Brodu - Komenského ulice
}

\section{Medieval pottery kiln from Uherský Brod - Komenského Street}

\section{Lenka Bartíková / Jaroslav Bartík}

\begin{abstract}
Abstrakt
Při záchranném archeologickém výzkumu v roce 2015 bylo v Uherském Brodě objeveno torzo vrcholně středověké hrnčirrské pece. Studie se zaměřuje na interpretaci nálezové situace a analýzu pozůstatků keramické vsádky. Získaná data jsou pak zasazena do kontextu dalších moravských měst a regionálního vývoje vrcholně středověké keramické produkce.

\section{Klíčová slova}

vrcholný středověk, město, hrnčiřská pec, keramická produkce, záchranný archeologický výzkum

Abstract

A 2015 archaeological rescue excavation in Uherský Brod revealed relics of a high medieval pottery kiln. The study is focused on interpretation of the find context and analysis of remnants of a ceramic kiln charge. The acquired data are then put into context of other Moravian towns and regional development of high medieval ceramic production.
\end{abstract}

\section{Key words}

High Middle Ages, town, pottery kiln, ceramic production, archaeological rescue excavation 


\section{1. Úvod}

V souvislosti s výstavbou nového polyfunkčního domu na křižovatce ulic Komenského a U Sboru v Uherském Brodě (obr. 1:A) proběhl v roce 2015 záchranný archeologický výzkum, při němž byla prozkoumána velká část původní městské parcely, na jejíž ploše se podařilo zdokumentovat stopy osídlení z mladšího pravěku, vrcholného středověku a novověku (Bartik 2015; Bartik - Chrástek - Novotný 2016, 319-320). Celkem bylo výzkumem odkryto 40 zahloubených objektů a několik dalších desítek kůlových jam představujících zpravidla relikty po vnitřních konstrukcích. K nejstarší fázi osídlení lze zařadit tři objekty (obj. 507, 510, 521) datované do staršího úseku kultury popelnicových polí (Bartik - Chrástek 2016, 231). Prostorově nejrozsáhlejší doklady lidských aktivit však pocházejí až z období vrcholného středověku (19 objektů) a novověku (17 objektů + jeden recentní výkop; obr. 1:B). Některé z novověkých objektů obsahovaly pozůstatky zděných kamenných či cihlových konstrukcí, které můžeme interpretovat jako odpadní jámy/jímky a sklípky. Příkladem nejzajímavějšího objektu z tohoto období je kompletně zachovaný kvadratický sklípek vyložený plochými kamennými deskami a cihlami, jehož vznik lze na základě nálezu mince (stavební obětiny) datovat na přelom 17. a 18. století (Bartik et al. 2016a). Nejmladší archeologické situace jsou na zkoumané parcele reprezentovány navážkovými vrstvami v prostoru dvora a relikty kamenných základů souvisejícími se zdejší zástavbou v průběhu 19. a 20. století.

Stavební vývoj parcely ve vrcholném středověku dokumentuje hned několik různých druhů struktur (obr. 1:B). Ve východní polovině zkoumané plochy byly odkryty pozůstatky čtyř suterénů nadzemních dřevo-hliněných domů (obj. 502-505). U dvou z nich se dochovalo i vstupní, do spraše vytesané schodiště a pozůstatky vnitřních konstrukcí v podobě různě velkých sloupo- vých a kůlových jam. Další zdokumentovanou strukturou je baterie pěti zásobnicových jam vakovitého až hruškovitého profilu (obj. 514, 519, 525, 532, 537), která byla uspořádána v řadě orientované $\mathrm{v}$ ose SZ-JV a umístěna na severním okraji parcely. Ve výplni dvou z uvedených zásobnic byly objeveny kumulace zvírecích kostí a několik celých skeletů domácích a hospodářských zvírat. Identifikováno bylo také tvarově pestré spektrum funkčně nespecifikovatelných zahloubených jam vyplněných odpadovým materiálem, které se v mnoha případech nacházely v superpozicích se staršími, ale i mladšími novověkými objekty. Poslední ze zdokumentovaných struktur byla determinována jako relikt středověké hrnčířské pece (obj. 509) s pozůstatky původní keramické vsádky. Předkládaný příspěvek je věnován zevrubné analýze výše zmíněné pece a z ní získané keramiky v kontextu dalších moravských analogií a regionálního vývoje vrcholně středověké keramické produkce.

\section{Poloha lokality}

Zkoumaná parcela se nachází v jihozápadní části centra Uherského Brodu, ve staré městské zástavbě v blízkosti středověkého opevnění města (dnes čp. 2676). Z hlediska vnitřní urbanistické struktury se jedná o východní okraj úzkého pásu parcel trojúhelníkovitě vykliňujících směrem k západu, které svým jižním okrajem přiléhaly k hradební zdi (obr. 1:A). Naproti ploše výzkumu stojí dnes gymnázium J. A. Komenského, pod nímž se měla podle písemných zpráv nacházet bratrská škola se hřbitovem a kaplí (Tomeček 2002, 70-71). GPS souřadnice středu lokality lze vztáhnout ke koordinátám: 49,0233583 ${ }^{\circ} \mathrm{N}$; 17,6444844 E (WGS-84). Po geografické stránce se plocha výzkumu rozprostírala na příkrém J až JZ svahu sklánějícím se k řece Olšavě, která protéká cca 650-700 m jižně od místa nálezu. Geologické podloží v centru města je tvořeno 


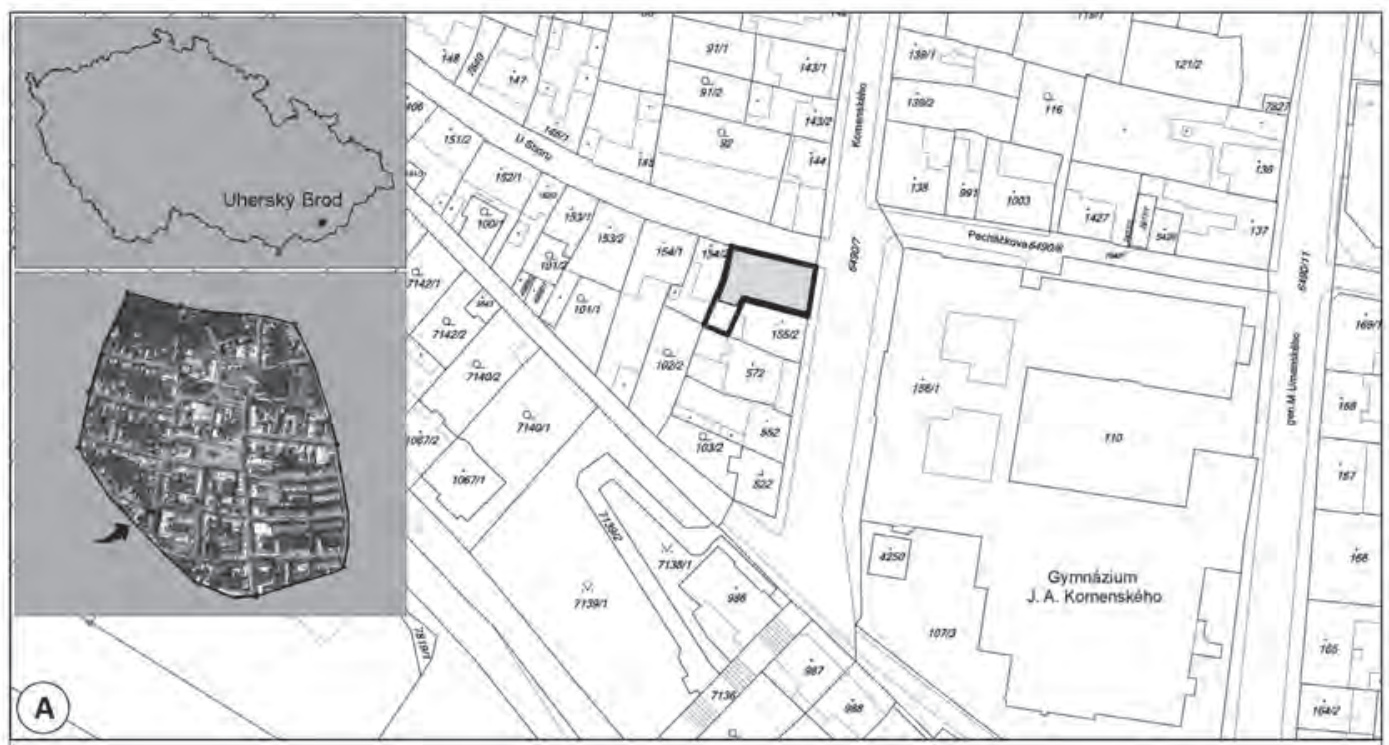

\section{Legenda}

plocha parcely

plocha vyzkumu
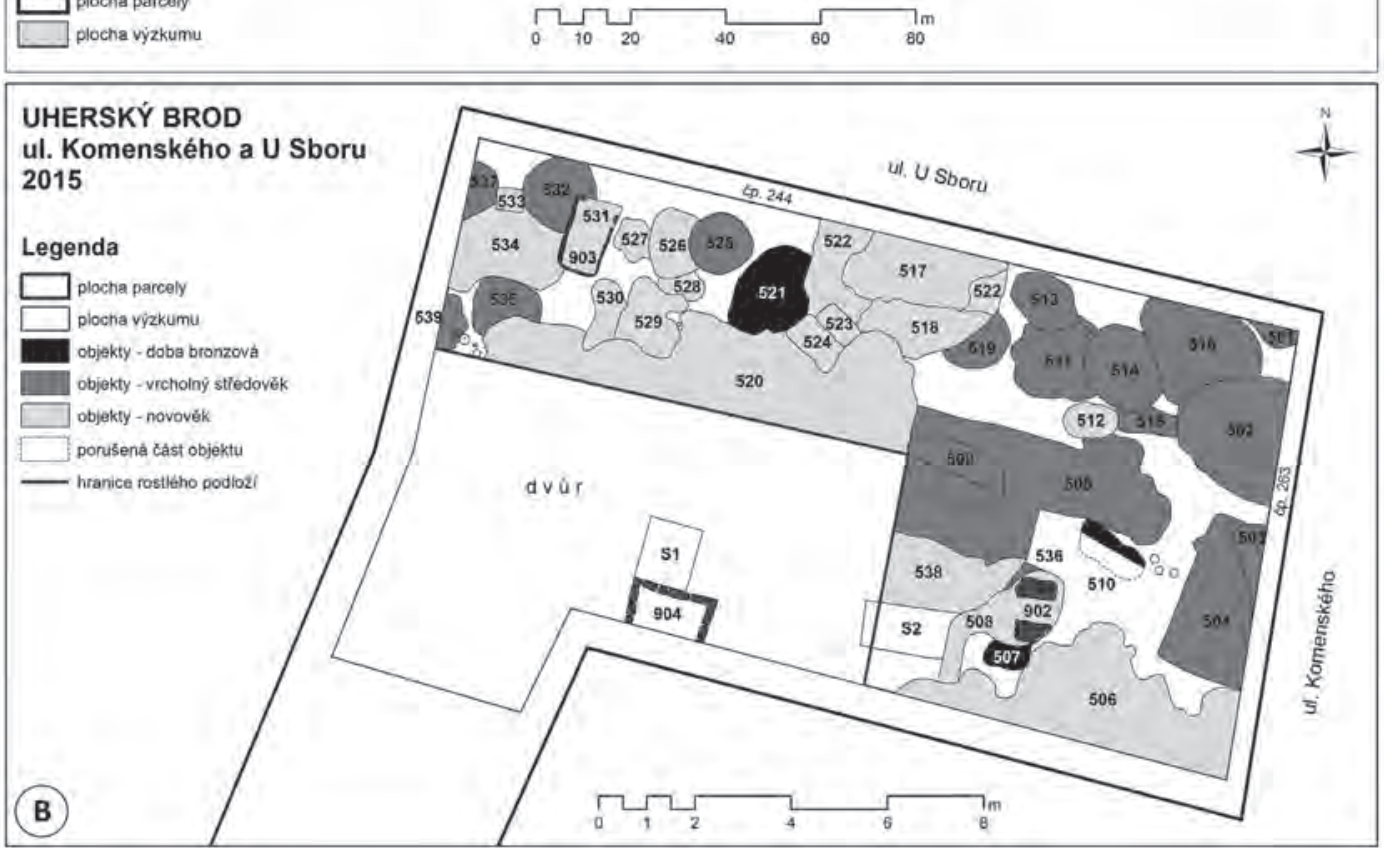

Obr. 1. Uherský Brod - ul. Komenského; A - poloha lokality a plochy výzkumu v rámci městské parcelace; B - planigrafie lokality s pozicí jednotlivých objektů rozdělených podle datace.

Fig. 1. Uherský Brod - Komenského St.; A - position of the site and the excavation area within the urban plots; $\mathrm{B}$ - planigraphy of the site showing the position of individual features divided by dating. 
převážně pískovci/jílovci, jíly a lupkem (Zemek eds. 1972; www.geology.cz), na rozdíl od některých jiných, již v minulosti zkoumaných poloh (např. Pavelčik 1995; Bartik et al. 2016b), se zde však podařilo doložit výskyt intaktních vátých spraší. Nadmořská výška současného terénu osciluje mezi 228-226 m n. m. Nejsvrchnější úroveň nálezových situací v severní části výzkumné plochy se pak nacházela $1,52 \mathrm{~m}$ pod úrovní povrchu.

\section{Nálezová situace}

Rozrušený objekt 509 se podařilo identifikovat v centrální části zkoumané parcely. U struktury byla zdokumentována dvojitá superpozice (obr. 2). Báze objektu byla zahloubena až $35 \mathrm{~cm}$ do svrchní části výplně staršího suterénu středověkého domu (obj. 505), přičemž po zániku funkce objektu 509 došlo v průběhu novověku na západní straně k jeho poškození objektem 520, který zničil prostor topeniště. Postupnými úpravami a planýrováním terénu $\mathrm{v}$ souvislosti s mladší zástavbou byla destruována také horní část klenby pece. Jižní část objektu byla výrazně poničena $\mathrm{v}$ rámci př́ípravných stavebních prací ještě před zahájením samotného archeologického výzkumu (recentní a pozdně novověké navážkové vrstvy v prostoru dvora byly z časových důvodů exkavovány strojově - při svahování terénu došlo k odkrytí objektu a jeho částečnému poškození ve vertikální ose; obr. 2, 4). I přes uvedené limitující zásahy lze dochovanou nálezovou situaci interpretovat jako relikt hrnčirrské pece. Nasvědčuje tomu nejen tvar a silně propálené stěny objektu, ale také nález rozdrcené keramické vsádky uvnitř (obr. 3:A-D), v rámci níž se objevily i silně deformované a přepálené kusy nádob.

Z hlediska identifikace jednotlivých konstrukčních prvků zůstala zachována větší část jednoho topného kanálu a v severovýchodní části objektu se podařilo zachytit také část stře- dového soklu, který byl zřejmě původně vyložen plochými kameny. Nalezeny byly ovšem jen dva na jeho okraji (obr. 2; 3:A, C; 4). Dále se v severní polovině dochoval základ stěny pece, respektive její klenby (mocnost se pohybovala okolo $5 \mathrm{~cm}$ ) a také hrana výkopu pro její stavbu. Dochované rozměry pece činí $252 \mathrm{~cm}$ na délku a $93 \mathrm{~cm}$ na širŕku. Původní rozměry pece můžeme na základě náznaků zakřivení pouze odhadovat. Maximální délka dosahovala pravděpodobně až $3 \mathrm{~m}$, její šíŕka se pak mohla pohybovat okolo $180 \mathrm{~cm}$. Zdokumentovaný topný kanál (obr. 4) měl mírně trapézovitý profil s plochým dnem a jeho výška nepřesáhla $20 \mathrm{~cm}$. Šírka kanálu kolísala od 25 do $32 \mathrm{~cm}$.

$\mathrm{Na}$ výrobu tělesa pece byla použita jemnozrnná hmota bez makroskopicky pozorovatelných příměsí (ojediněle pouze drobné kaménky), jež byla vypálena do odstínů šedé až světle hnědošedé barvy. Uloženiny ve starším zahloubeném objektu 505 nacházející se bezprostředně pod pecí byly žárem zabarveny do odstínů rezavě hnědé a oranžové barvy (obr. 3:D, E). Výplň samotné pece sestávala ze tří makroskopicky odlišitelných uloženin. Na východním okraji topného kanálu spočívala tenká tmavě hnědošedá vrstva silně obohacená uhlíky. Převládající centrální část výplně byla tvořena nehomogenní světle hnědožlutou uloženinou s čočkami podložní spraše a uhlíků, která obsahovala i drobné úlomky mazanice a také větší množství fragmentů keramických nádob a jejich torz (obr. 3:A-D), jež se koncentrovaly především v prostoru topného kanálu a jež interpretujeme jako zbytky po vsádce ponechané v peci. Svrchní partii výplně uzavírala již jen ve středu objektu světle šedohnědá jílovitá vrstva opět s příměsemi drobných uhlíků, hrudek mazanice a keramických fragmentů, které už ovšem nemusejí nutně souviset s pozůstatky poslední vypalované vsádky, ale do výplně se mohly dostat až později v souvislosti s depozičními procesy. 


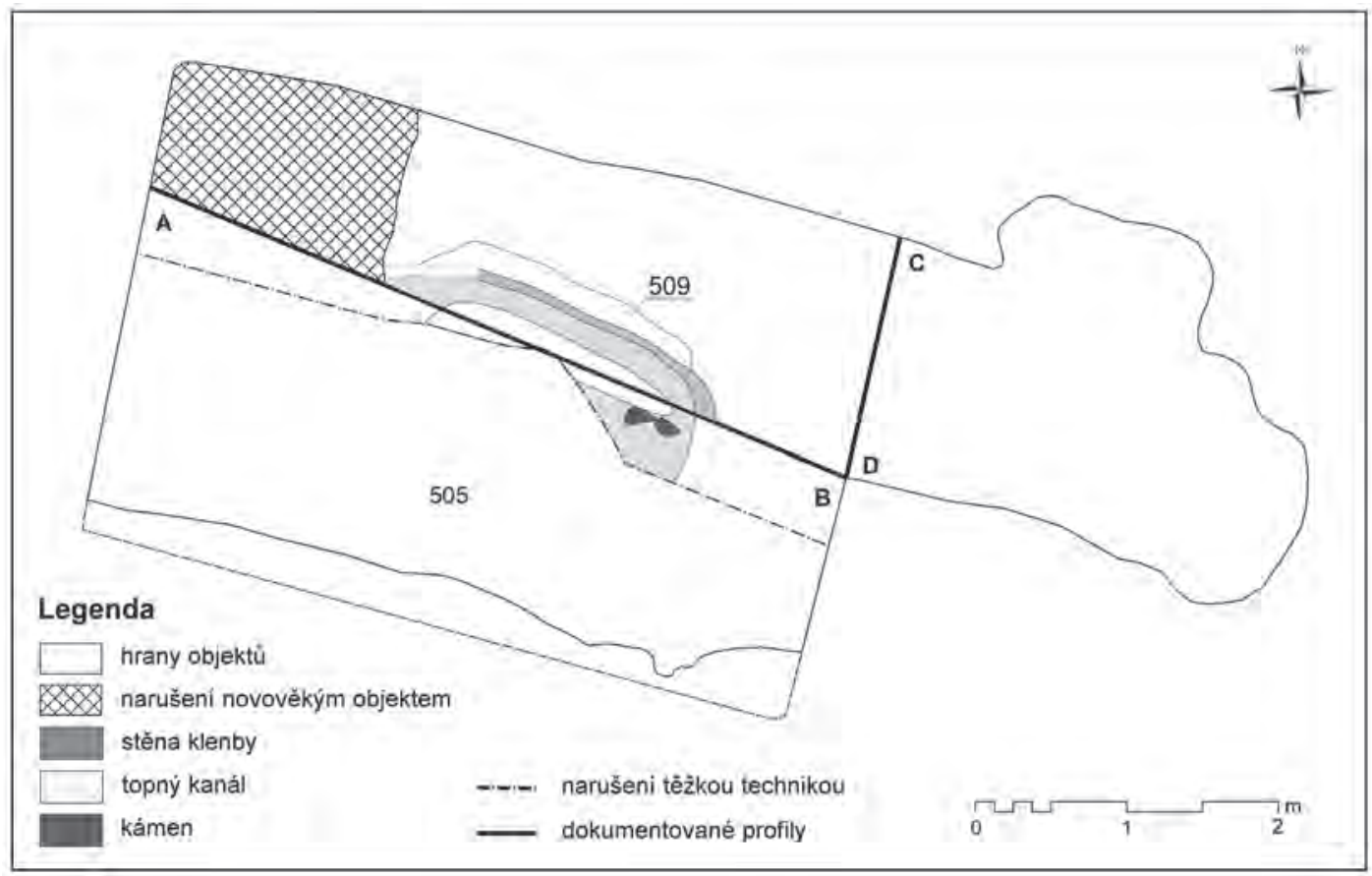

Obr. 2. Půdorys dochované části vrcholně středověké pece a její vztah k okolním zahloubeným objektům, se kterými byla v superpozici.

Fig. 2. Ground-plan of the preserved part of a high medieval kiln and its relationship to surrounding sunken features in superposition.

\section{Středověké hrnčířské pece na JV Moravě}

Na rozdíl od keramiky, která bývá při archeologických výzkumech získávána ve velkém počtu, jsou objevy hrnčířských pecí spíše ojedinělou záležitostí. Jedním z možných vysvětlení může být fakt, že keramika se mohla pálit také v dalších objektech, které nelze jednoznačně jako vypalovací pece interpretovat. Snadno zaměnitelné s jiným typem objektu mohou být zejména jednoprostorové pece, jejichž spojitost s výrobou keramiky bývá jednoznačně prokazatelná jen při nálezu vsádky uvnitř. Větší spojitost s výpalem keramiky mívají především dvoukomorové pece, které se dle vzájemného postavení topného a vypalovacího prostoru dále dělí na pece vertikální, kdy je topeniště překryté roštovým dnem pece, a pece horizontální, u nichž se topeniště nachází před topnou komorou. Pece se středovým soklem překrytým rošty bývají někdy označovány za přechodný typ (Nekuda - Reichertová 1968, 40-48; Thér 2009, 92-93; Varadzin 2010, 27-28; Procházka 2015, 217-219).

Vzhledem k výše popsaným porušením lze celkovou podobu analyzované uherskobrodské pece s určitou mírou pravděpodobnosti pouze předpokládat. S ohledem na tvar dochovaných částí je možné uvažovat o př́ílušnosti prozkoumaného torza k vertikálním pecím se středovým soklem (typ 2b). Uvedený typ pece se prozatím jeví na Moravě jako dominantní a jeho výskyt je kladen do rozmezí 13.-15./16. století. Uvažuje se, že do moravského prostředí se dostal kolonizací z dolnorakouského Podunají (Procházka 2015, 217-219). 

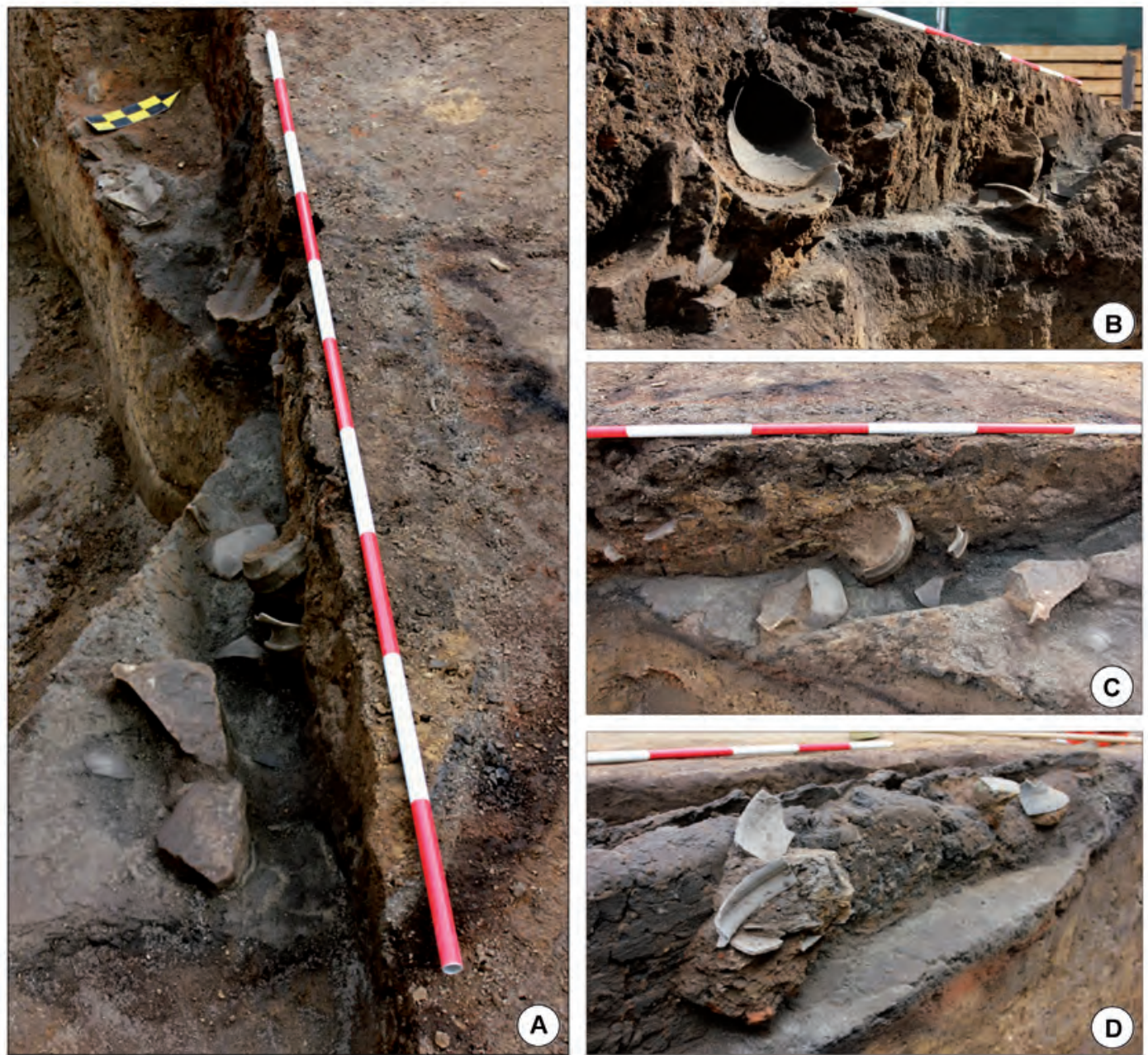

A)
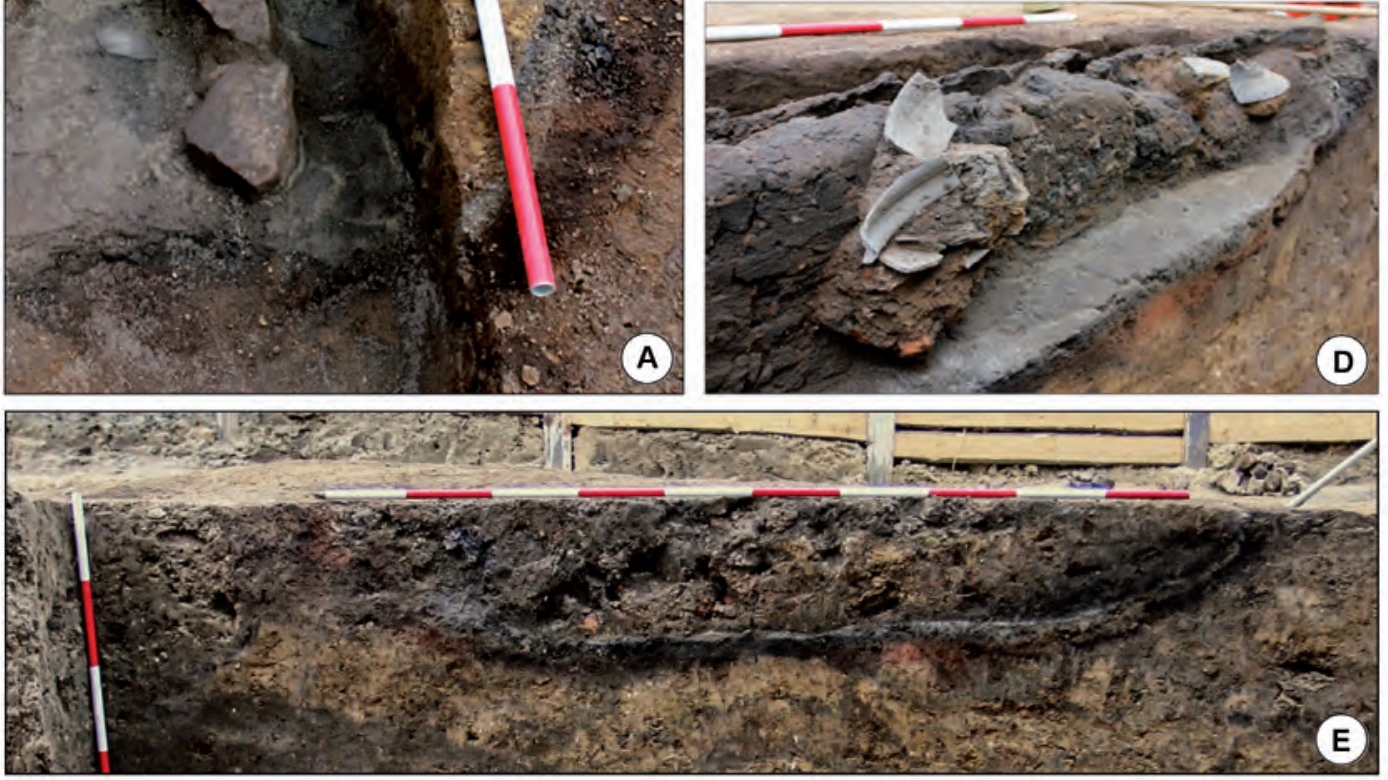

Obr. 3. Fotografická dokumentace pece. A-D: pozůstatky keramické vsádky ve výpalovém kanálu; E: dokumentovaný profil výplně pece v její severní části (foto J. Bartík).

Fig. 3. Photographic documentation of the kiln. A-D: remnants of ceramic kiln charge in the stoking channel; $E$ : documented section of the infill in the northern part of the kiln (photo J. Bartík). 


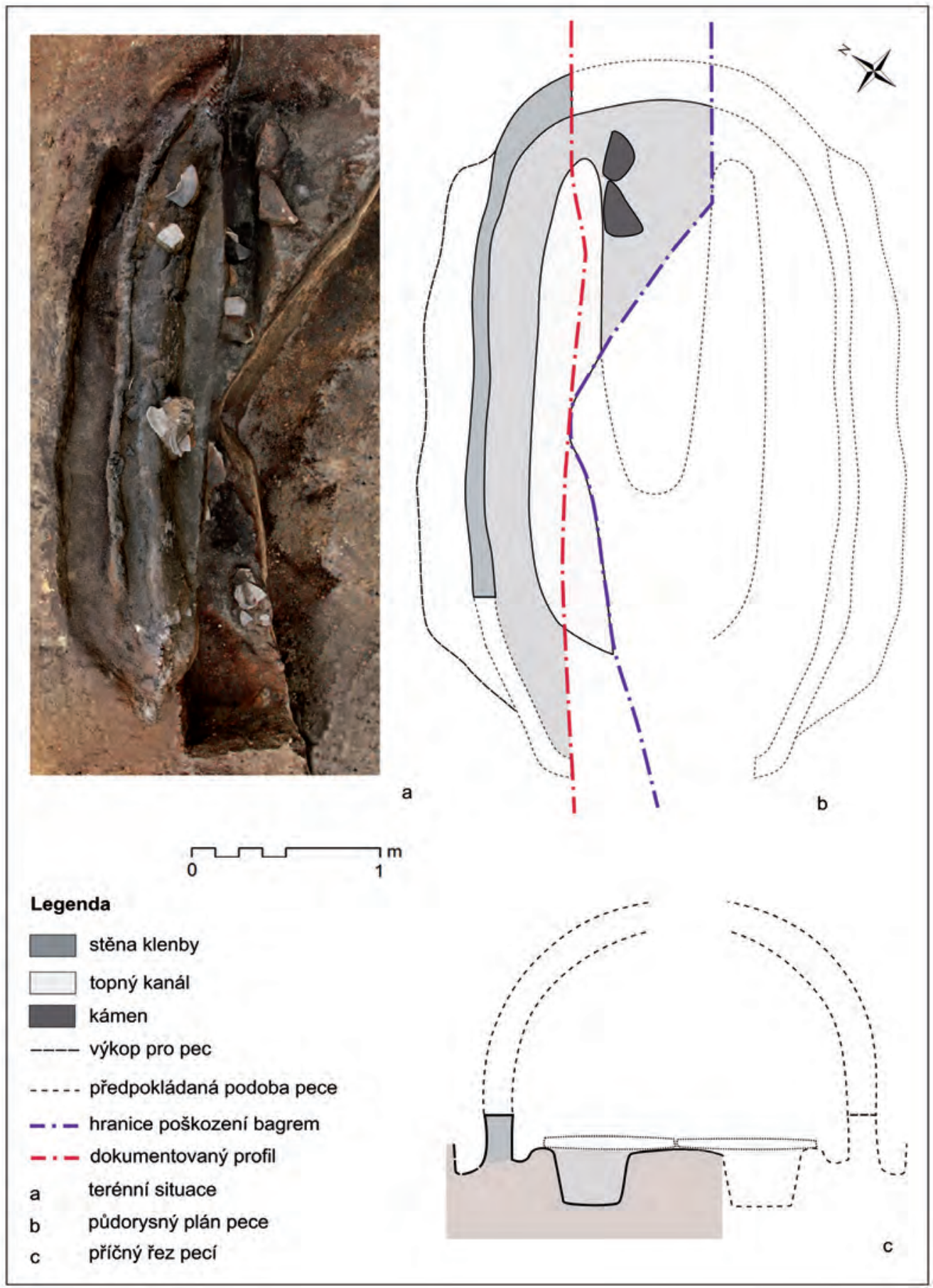

Obr. 4. Půdorysný plán a př́ičný profil pece s vyznačením dochovaných konstrukčních prvků.

Fig. 4. Ground-plan and cross-section of the kiln with preserved construction elements.documented section of the infill in the northern part of the kiln (photo J. Bartík). 
Pokud se zaměříme pouze na region JV Moravy, tak i zde bylo objeveno hned několik jednokomorových pecí se středovým soklem. Podobná pec byla prozkoumána například v nedalekém Starém Městě u Uherského Hradiště v trati Na Dvorku (Galuška 2003, 591-606). Analogie můžeme najít také u pecí v dílenském komplexu na Milíčově náměstí v Kroměříži (Chybová 2009, 122). Zmíněné pece je možné datovat do průběhu 13.-14. století, přičemž hrnčířská dílna na Milíčově náměstí v Kroměřiži fungovala prokazatelně ještě v 15. století. Další vrcholně středověké hrnčířské pece byly v rámci regionu jihovýchodní Moravy zjištěny v Holešově a také ve Starém Městě u Uherského Hradiště v polohách $\mathrm{Na}$ Kostelíku a Za Zahradou. Na prrítomnost pece v rámci holešovské hrnčírsské dílny z poloviny 16. století ukazují zejména velké kusy mazanice. Samotný půdorys pece se ovšem nepodařilo zachytit. V poloze Na Kostelíku ve Starém Městě byla odkryta obdélná předpecní jáma a topná komora pece z poslední třetiny 13. století. Další komplex čtyř pecí z počátku 14. století byl objeven mimo vlastní osadu. Zadní část vypalovací komory a roštu pece pak pochází z polohy Za Zahradou (Nekuda 1963, 81; Snáśil 1979, 1982a, 1982b, 1983). Destrukce keramické pece se zbytky vsádky je uváděna ještě z Hluku (ul. Hlavní, č. p. 460). Zde bylo při kopání sklepa rodinného domu odkryto torzo pece obsahující sedm keramických nádob v různém stupni zachování a dvě pokličky. Keramika z pece klade dobu jejího fungování do přelomu 13./14. století (Mitáček 2011).

\section{Analýza keramiky}

Přestože byl objekt pece poškozen novověkými a recentními zásahy, podařilo se z ní získat reprezentativní soubor nálezů čítající 1174 zlomků keramiky. Z těchto fragmentů bylo vyčleněno celkem 362 jedinců keramických nádob.

Velká část souboru je tvořena zlomky výdutí a dalšími atypickými fragmenty, u kterých nelze určit typ původní nádoby. Z ostatních zlomků byly zejména na základě typologie okrajů vyčleněny hrnce a hrnec s uchem, zvonovité poklice, džbány, mísy, pohár a poklice kónická. Mezi částmi nádob dominují zlomky výdutí a zlomky okrajů. Ostatní části nádob jsou zastoupeny v menší míre, plece, dno a ucha (tab. 1). Pouze jedna nádoba se dochovala celá (obr. 9:6) a v jednom př́ípadě se podařilo po slepení fragmentů zrekonstruovat horní část menšího hrnce (obr. 8:8).

\begin{tabular}{|l|c|c|}
\hline Typ nádoby & Ks & $\%$ \\
\hline Neurčitelný & 241 & 66,6 \\
\hline Hrnec & 82 & 22,7 \\
\hline Zvonovitá poklice & 21 & 5,8 \\
\hline Džbán & 10 & 2,8 \\
\hline Mísa & 5 & 1,4 \\
\hline Hrnec s uchem & 1 & 0,3 \\
\hline Pohár & 1 & 0,3 \\
\hline Kónická poklice & 1 & 0,3 \\
\hline Celkem & $\mathbf{3 6 2}$ & $\mathbf{1 0 0}$ \\
\hline Č́ást nádoby & Ks & $\%$ \\
\hline Výdut' & 147 & 40,6 \\
\hline Okraj & 119 & 32,9 \\
\hline Plece & 58 & 16 \\
\hline Dno & 32 & 8,8 \\
\hline Ucho & 5 & 1,4 \\
\hline Celý tvar & 1 & 0,3 \\
\hline Celkem & $\mathbf{3 6 2}$ & $\mathbf{1 0 0}$ \\
\hline
\end{tabular}

Tab. 1. Zastoupení jednotlivých typů a částí nádob.

Tab. 1. Representation of individual types and parts of vessels.

Okraje džbánů jsou převážně jednoduché nebo jednoduché vyhnuté a okruží (obr. 6:3945). Okraje hrnců (tab. 2) jsou ve většině případů tvarovány do okruží (obr. 5) a ve větší míře se rovněž objevují okraje seříznuté kuželovitě/ válcovitě (obr. 6:1-19). Ojedinělými kusy jsou pak zastoupeny okraje jednoduché, jednoduché 

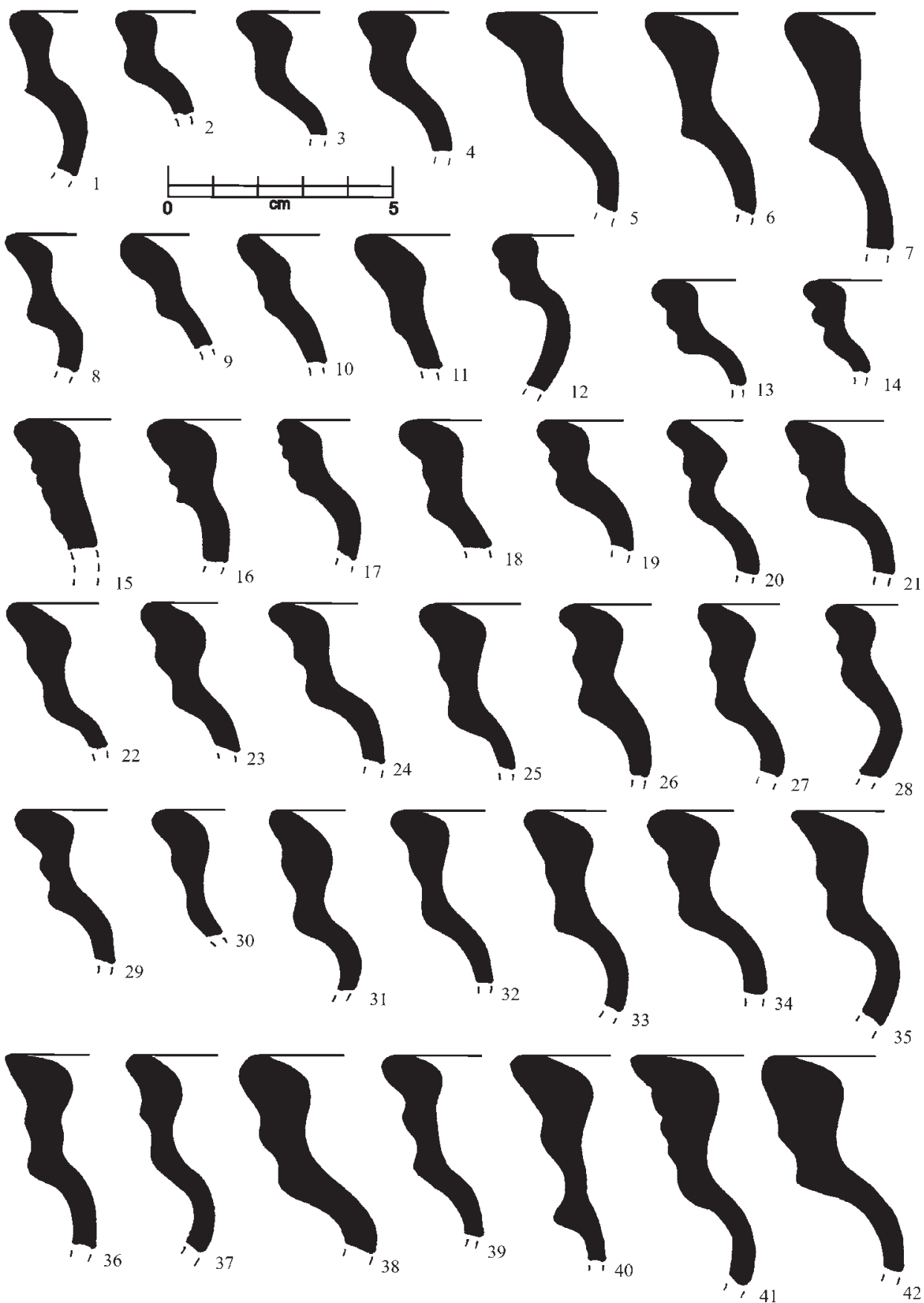

Obr. 5. Výběr okrajů nalezených ve výplni pece.

Fig. 5. Selection of rims from the kiln infill. 
vyhnuté nebo zesílené (obr. 6:24-27), přehnuté (obr. 6:20-23), vzhůru vytažené (obr. 6:31-33), římsovité (obr. 6:28, 29), rozšířené profilované (obr. 6:30) a vodorovně seříznuté (obr. 6:34). Mísy mají okraje nádob jednoduché rozšsiřrené různě seříznuté (obr. 6:35-38). Okraj kónické poklice je rozšířený na obě strany a tento typ okraje se ve většině případů objevuje rovněž u poklic zvonovitých (tab. 2; obr. 6:51-54). Dále se u zvonovitých poklic vyskytují dovnitř zesílené a zahnuté okraje (obr. 6: 46-48), dovnitř zesílené (obr. 6:49-50) a ojediněle také ven vyhnuté okraje (obr. 6:55). Hrdla nádob jsou převážně konkávní, méně se objevují hrdla nálevkovitá nebo kuželovitá. Dna jsou rovná s hráněným šikmým nebo rozšsiřreným okrajem, méně často se vyskytují dna se zaobleným šikmým okrajem. Dochovaná ucha jsou tažená, oválného průřezu a pouze v jednom př́ípadě se objevilo tažené ucho kruhového průřezu.

\begin{tabular}{|l|c|c|}
\hline Okraje hrnců & Ks & $\%$ \\
\hline Okruží & 45 & 54,9 \\
\hline Seříznutý kuželovitě/válcovitě & 21 & 25,6 \\
\hline Jednoduchý - varianty & 4 & 4,9 \\
\hline Přehnutý & 4 & 4,9 \\
\hline Vzhůru vytažený & 4 & 4,9 \\
\hline Římsovitý & 2 & 2,4 \\
\hline Rož̌írený profilovaný & 1 & 1,2 \\
\hline Vodorovně seř́iznutý & 1 & 1,2 \\
\hline Celkem & $\mathbf{8 2}$ & $\mathbf{1 0 0}$ \\
\hline Okraje zvonovitých poklic & Ks & $\%$ \\
\hline Rož̌iřrený na obě strany & 7 & 41,2 \\
\hline Dovnitř zesílený a zahnutý & 5 & 29,4 \\
\hline Dovnitř zesílený & 4 & 23,5 \\
\hline Ven vyhnutý & 1 & 5,9 \\
\hline Celkem & $\mathbf{1 7}$ & $\mathbf{1 0 0}$ \\
\hline
\end{tabular}

Tab. 2. Zastoupení jednotlivých typů okrajů hrnců a zvonovitých poklic.

Tab. 2. Representation of different types of rims and bell-shaped lids.
Tvar nádob nebylo možné vzhledem k fragmentárnosti souboru hodnotit. Avšak na základě několika větších zlomků výdutí je možné předpokládat, že tvar těl hrnců byl spíše soudkovitý. Některé větší zlomky okrajů s dochovanou částí výdutě rovněž naznačují, že se jednalo o varianty bez odsazení hrdla a plecí. Rovněž nízký počet dochovaných uch v souboru ukazuje, že ve většině př́ípadů se jedná o bezuché hrnce.

Vzhledem k poměrně velké fragmentárnosti bylo možné určit pouze průměry okrajů a den nádob. Průměr okrajů nádob se nejčastěji pohyboval v rozmezí 100-220 mm, u den je to pak 80-120 mm. Spíše ojediněle se objevují nádoby s větším průměrem okraje v rozmezí 230-280 mm a výjimečnou záležitostí je průměr okraje $340 \mathrm{~mm}$. V menší míře se rovněž objevují větší průměry den v rozmezí 130-150 mm a 190-200 mm. V několika případech se vyskytují rovněž malá dna o průměru 70-75 mm.

Keramická třída byla u keramiky určována na základě několika vlastností, kterými jsou obsah grafitu a slídy, zrnitost a množství ostřiva a typ výpalu. V souboru z pece bylo zjištěno celkem 21 variant těchto vlastností. Jednotlivé varianty byly seskupeny do 5 základních skupin (tab. 3), přičemž naprostá většina fragmentů byla vyrobena z keramické hmoty náležící první skupině. Jedná se o keramiku bez příměsi grafitu i slídy, s jemnozrnným ostřivem, vypálenou v redukční atmosféře. Hmota obsahovala převážně střední, případně malý obsah ostřiva, v ojedinělých případech se objevilo větší množství. Do této skupiny byly zahrnuty rovněž dva fragmenty s velmi jemnozrnným (prachovým) ostřivem. U některých zlomků byl zjištěn oxidační přežah, který mohl být způsoben sekundárně, jak naznačuje několik zlomků s oxidačním přepálením na některých lomech. V menší míře je zastoupena keramika bez grafitu s drobnou příměsí slídy s jemnozrnným ostřivem vypálená $\mathrm{v}$ redukční atmosféře, která byla zařazena do 


$$
\begin{aligned}
& 54999419 \\
& 1999999 \\
& 9199199 \\
& \text { T6rs? } \\
& \text { 1577.7 } \\
& \text { 1) }
\end{aligned}
$$


třetí skupiny. Příměs slídy je tvořena drobnými zrníčky v malém obsahu, přičemž v tomto případě není možné určit, zda se jedná o záměrnou příměs nebo přirozený obsah $\mathrm{v}$ některé ze základních složek keramické hmoty (typicky písčité ostřivo). Několika zlomky je zastoupena čtvrtá skupina charakterizovaná keramickou hmotou bez př́iměsí, s jemnozrnným ostřivem malého až středního obsahu, s oxidačním výpalem. Ojediněle se v rámci této skupiny objevily fragmenty vypálené v oxidační atmosféře s redukčním přežahem. Pouze ojediněle se objevují fragmenty náležící druhé a páté skupině. V případě druhé skupiny se jedná o keramickou hmotu bez příměsí, se středně hrubozrnným ostřivem a redukčním výpalem. Pátá skupina je charakterizována keramickou hmotou bez grafitu, s drobnou příměsí slídy, prachovým až jemnozrnným ostřivem a výpalem v oxidační atmosféře $s$ redukčním přežahem. Sendvičový efekt byl pozorován u 8 jedinců náležejících k první keramické skupině. Zároveň byli v rámci této skupiny zjištěni 3 jedinci s úpravou povrchu potuhováním. Jiný způsob úpravy povrchu nebyl u keramiky z pece pozorován.

\begin{tabular}{|l|c|c|}
\hline Keramická skupina & Ks & $\%$ \\
\hline Skupina 1 & 311 & 85,9 \\
\hline bez grafitu, bez slídy, jemnozrnná, redukce \\
\hline Skupina 2 & 6 & 1,7 \\
\hline bez grafitu, bez slídy, středně hrubozrnná, redukce \\
\hline Skupina 3 & 27 & 7,5 \\
\hline bez grafitu, drobná příměs slídy, jemnozrnná, redukce \\
\hline Skupina 4 & 14 & 3,9 \\
\hline bez grafitu, bez slídy, jemnozrnná, oxidace \\
\hline Skupina 5 & 4 & 1,1 \\
\hline bez grafitu, drobná příměs slídy, prachová, oxidace \\
\hline Celkem & 362 & 100 \\
\hline
\end{tabular}

Tab. 3. Zastoupení jednotlivých keramických skupin.

Tab. 3. Representation of individual ceramic groups.
S keramickou třídou souvisí rovněž barva keramiky, která je v rámci souboru nejčastěji středně až tmavě šedá a hnědošedá, většinou v kombinaci se světlejší barvou jádra (kontrastní rozdíl mezi tmavou barvou vnějšího a vnitřního nebo pouze vnějšího povrchu a světlou barvou jádra). Keramika pálená oxidačně nesla barvu okrovou, středně hnědou až oranžovou.

Nádoby byly vyráběny vytáčením z jednoho kusu hlíny na kruhu, jen ojediněle bylo pozorováno stáčení na kruhu, tedy technika, kdy je základní tvar nádob vyroben z válečků a následně za pomoci kruhu opracován a dotvarován (Běhounková 2018, 13-14). U některých zlomků nebylo možné určit techniku výroby zejména z důvodu velké fragmentarizace nebo nedochování vnitřního povrchu nádoby, na němž jsou stopy po výrobě nejlépe znatelné.

Zdobeno bylo celkem 53,6 \% (194 ks) jedinců z keramického souboru (tab. 4). Nejběžnějším typem výzdoby jsou ryté linie (obr. 7:11; obr. 9:6), které se objevují nejen na výdutích a plecích nádob, ale poměrně často rovněž vně okraje. Druhým nejpočetnějším typem výzdoby jsou vývalkové šroubovice, které byly zjištěny na výdutích a plecích nádob (obr. 7:15). Ve větším počtu se objevuje také oběžná rytá šroubovice (obr. 7:3), zjištěná na výdutích a plecích nádob, a jednoduchá či zdvojená vlnice na výduti nebo vně okraje nádob (obr. 7:5, 7; obr. 8:3; obr. 9:1). U několika jedinců se objevují další typy výzdoby, jako jsou pásy čtvercových radélek na výdutích, plecích i okrajích (obr. 7: 8, 9, 14; obr. 8:7; obr. 9:3), trojúhelníková radélka na plecích, výdutích a okrajích nádob (obr. 7:2, 6, 10; obr. 8:5), vícenásobná stupňovitá šroubovice na plecích a výdutích, obdélníčkovitá či lichoběžníkovitá radélka na výdutích, plecích a okrajích, kombinace vlnic a rytých rýh na plecích a výdutích (obr. 8:4; obr. 9:4), vícenásobné vseky na uchu (obr. 9:5), kombinace čtvercových radélek a rytých rýh na plecích a výdutích (obr. 8:2, 9; obr. 9:2) nebo plastická lišta trojúhelníkovitého 


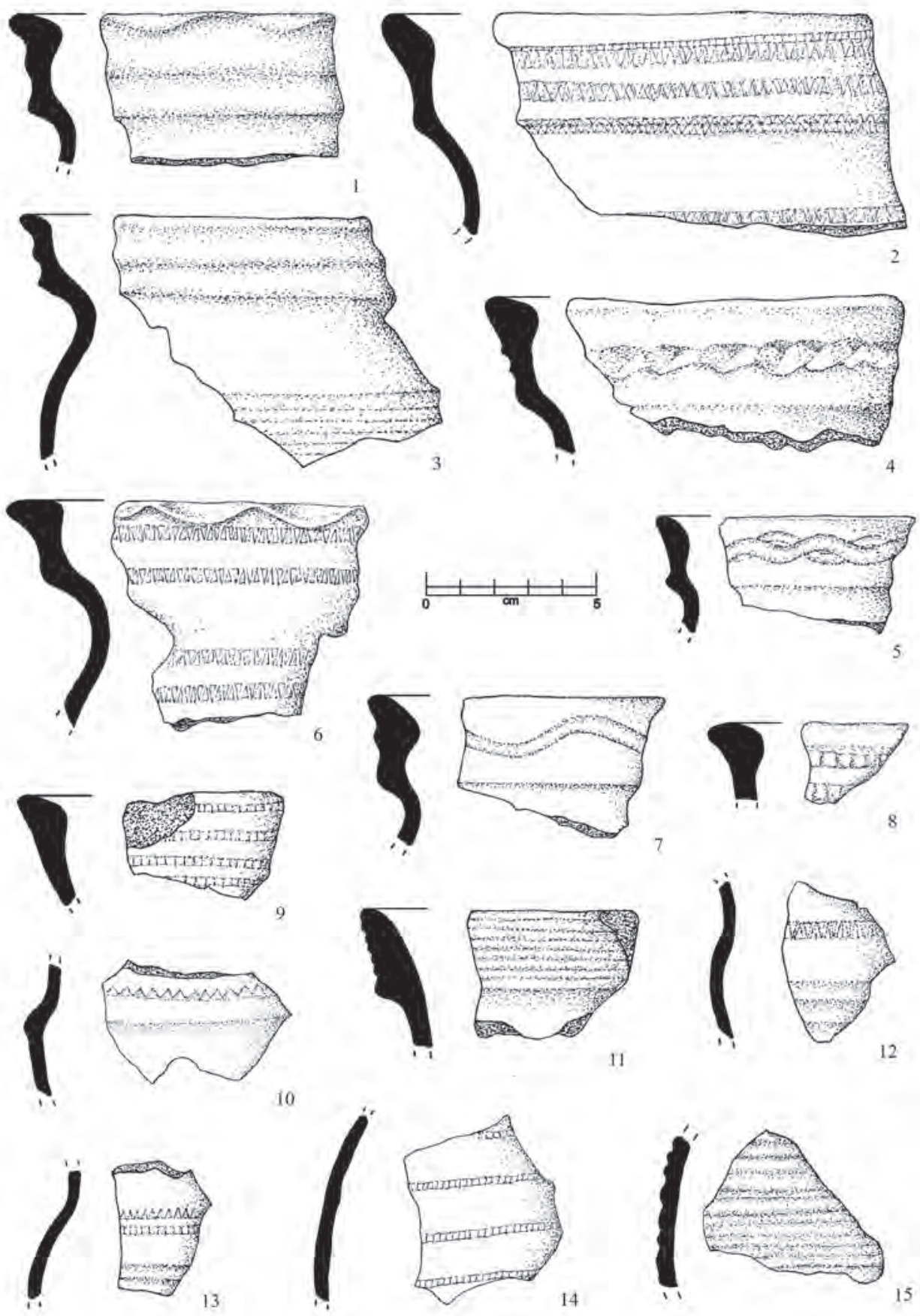

Obr. 7. Výběr keramiky z uherskobrodské pece.

Fig. 7. Selection of pottery from the kiln in Uherský Brod. 


\begin{tabular}{|c|c|c|c|}
\hline Typ výzdoby & Motiv výzdoby & Ks & $\%$ \\
\hline \multirow{6}{*}{ Rytá } & Ryté linie & 56 & 28,9 \\
\hline & Vývalková šroubovice & 31 & 16 \\
\hline & Oběžná rytá šroubovice & 25 & 12,9 \\
\hline & Vlnice na výduti/vně okraje & 13 & 6,7 \\
\hline & Stupňovitá šroubovice & 10 & 5,2 \\
\hline & Kombinace vlnic a rýh & 7 & 3,6 \\
\hline \multirow{3}{*}{ Radélko } & Pás čtvercových radélek & 10 & 5,2 \\
\hline & Trojúhelníkové radélko & 10 & 5,2 \\
\hline & Obdélníkové/lichoběžníkovité radélko & 8 & 4,1 \\
\hline \multirow{6}{*}{$\begin{array}{l}\text { Kombinace radélka a } \\
\text { ryté }\end{array}$} & Kombinace čtvercového radélka a rytých rýh & 4 & 2,1 \\
\hline & Kombinace trojúhelníkového radélka a vývalkové šroubovice & 1 & 0,5 \\
\hline & Kombinace obdélníkového radélka a rýh & 1 & 0,5 \\
\hline & Kombinace různě lomených radélek a rýh & 1 & 0,5 \\
\hline & Kombinace trojúhelníkových radélek a rýh & 1 & 0,5 \\
\hline & Kombinace lichoběžníkovitých radélek a rýh & 1 & 0,5 \\
\hline \multirow{2}{*}{ Plastická } & Trojúhelníkovitá lišta & 4 & 2,1 \\
\hline & Vymáčknuté ovály na okraji & 2 & 1 \\
\hline Vleštování & Vleštované motivy & 1 & 0,5 \\
\hline \multirow{3}{*}{ Vrypy, vseky } & Vseky na uchu & 5 & 2,6 \\
\hline & Trojúhelníkovité vrypy na okraji & 1 & 0,5 \\
\hline & Nehtovité vrypy na okraji & 1 & 0,5 \\
\hline Kombinace vrypů a rýté & Kombinace vrypů a rýh & 1 & 0,5 \\
\hline Celkem & & 194 & 100 \\
\hline
\end{tabular}

Tab. 4. Zastoupení jednotlivých typů výzdoby.

Tab. 4. Representation of individual types of decoration.

průřezu. Pouze ojediněle se vyskytuje výzdoba v podobě prstem vymáčknutých oválů na okraji (obr. 7:1,4), vleštovaných motivů na výduti, trojúhelníkovitých vrypů na okraji (obr. 8:1), nehtovitých vrypů na okraji, kombinace vývalkové šroubovice a trojúhelníkovitých radélek na výduti (obr. 8:8), kombinace vrypů a rýh na výduti (obr. 8:6), kombinace obdélníkovitých radélek a rýh na výduti, kombinace různě lomených radélek a rýh na výduti (obr. 7:13), kombinace trojúhelníkovitých radélek a rýh na plecích (obr. 7:12) nebo kombinace nepravidel- ných lichoběžníkovitých radélek a rýh na plecích. Spojitost určitého typu výzdoby s typem nádoby nebyla prokázána. Na okrajích se objevuje výzdoba zejména na okružích a jednoduchých variantách okrajů.

Fragmenty dochované v keramickém souboru z pece jsou ve většině př́ípadů ostrohranné. Velikost zlomků (tab. 5) je převážně do $36 \mathrm{~cm}^{2}$, méně často se objevují zlomky o velikosti do $9 \mathrm{~cm}^{2}$ a zlomky o velikosti do $81 \mathrm{~cm}^{2}$. Spíše výjimečné jsou velké fragmenty o velikosti do $144 \mathrm{~cm}^{2}$. 

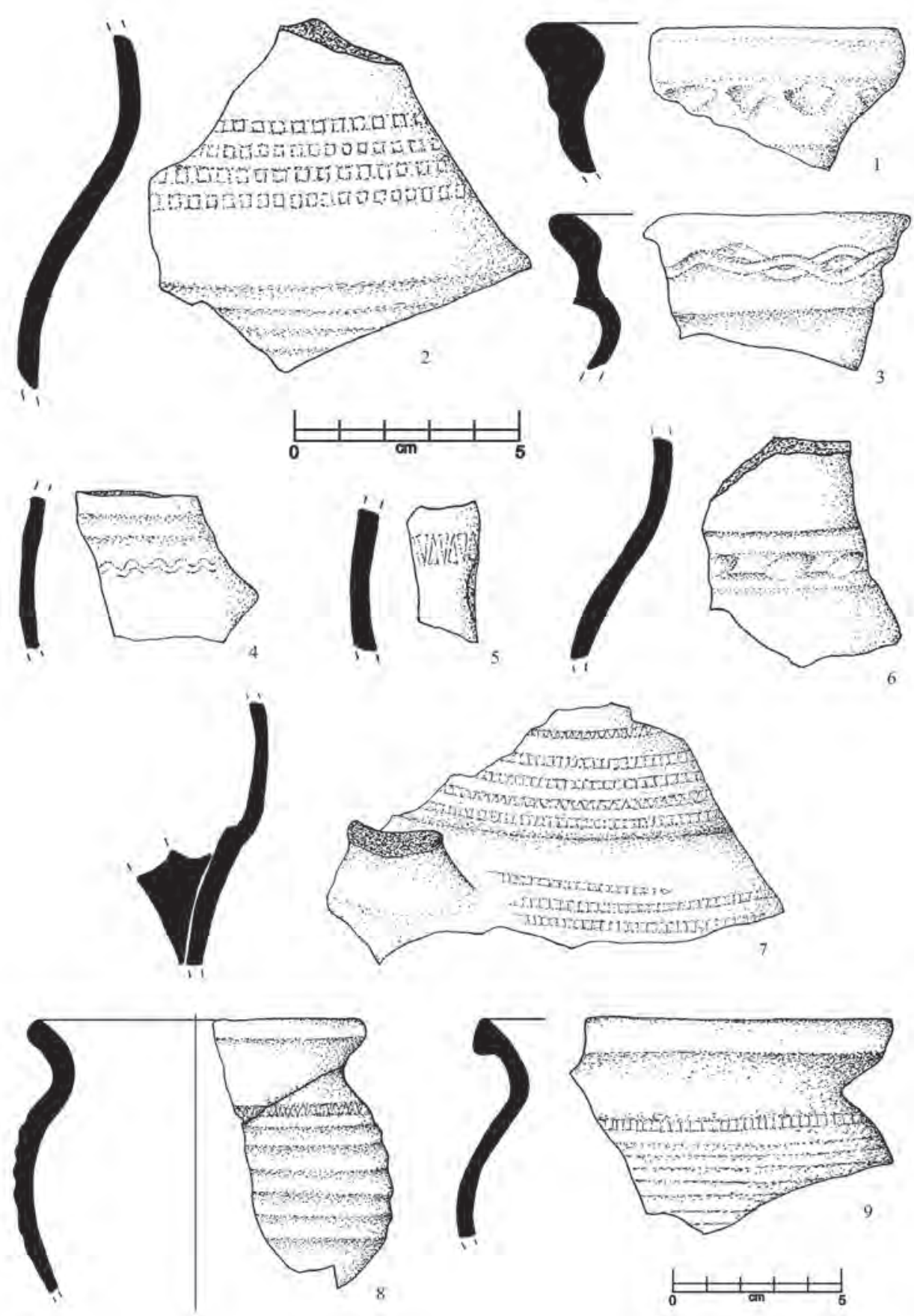

Obr. 8. Výběr keramiky z uherskobrodské pece.

Fig. 8. Selection of pottery from the kiln in Uherský Brod. 


\begin{tabular}{|l|c|c|}
\hline Fragmentarizace & Ks & $\%$ \\
\hline Do $9 \mathrm{~cm}^{2}$ & 64 & 17,7 \\
\hline Do $36 \mathrm{~cm}^{2}$ & 219 & 60,5 \\
\hline Do $81 \mathrm{~cm}^{2}$ & 58 & 16 \\
\hline Do $144 \mathrm{~cm}^{2}$ & 20 & 5,5 \\
\hline Celá nádoba & 1 & 0,3 \\
\hline Celkem & $\mathbf{3 6 2}$ & $\mathbf{1 0 0}$ \\
\hline
\end{tabular}

Tab. 5. Zastoupení velikostních skupin fragmentů.

Tab. 5. Representation of fragment size groups.

Jedinou celou dochovanou nádobou je pohár se třemi výlevkami (obr. 9:6), který byl rozlomen na čtyři části, přičemž se jednalo o jednu velkou část nádoby a tři zlomky okraje o velikosti do $36 \mathrm{~cm}^{2}$. Výška poháru je $118 \mathrm{~mm}$, průměr horní části okraje je $90 \mathrm{~mm}$ a jeho nejširší část dosahuje $98 \mathrm{~mm}$. Na okraj navazuje konkávní hrdlo, jehož nejužší část se nachází $20 \mathrm{~mm}$ od vrcholku okraje. Průměr hrdla je $73 \mathrm{~mm}$. Soudkovité tělo poháru nese mělkou žlábkovanou výzdobu na maximální výduti, jejíž průměr je 85 mm. Rovné hraněné dno má průměr $47 \mathrm{~mm}$. Pohárek je vyroben z jemnozrnné hmoty bez příměsi slídy a vypálen $\mathrm{v}$ redukční atmosféře do odstínů středně šedohnědé barvy. Nádoba nese stopy výroby na hrnčířském kruhu, jako jsou jemné spirálovité rýžky po prstech a téměř nepatrný pozůstatek středového pupku na středu vnitřní strany dna. Jednoduchý zatažený okraj pohárku má na svém vrcholu tři hubičky v pravidelných rozestupech. Hubičky byly pravděpodobně vytvořeny stlačením okraje prstem.

\section{Interpretace a diskuze}

Z analýzy nálezové situace a keramického souboru pocházejícího především z výplně jednoho dochovaného topného kanálu vyplývá několik struktur, zasluhujících si pokus o jejich interpretaci. První se týká umístění keramické vsád- ky v peci. Vzhledem k velkému počtu okrajů a celkově horních partií nádob lze předpokládat, že přinejmenším jedno patro nádob bylo během posledního výpalu uloženo okrajem dolů, respektive dnem vzhůru. V potaz ovšem musí být brán fakt, že pec byla částečně poškozena, a tudíž ani studovaná kolekce keramiky nebyla kompletní. Další otázkou k diskuzi je samotný zánik pece. Několik málo zlomků se znaky oxidace $\mathrm{v}$ rámci jinak redukčně pálené keramiky nasvědčují, že během výpalu došlo ke změně atmosféry. Na nezanedbatelném množství keramických fragmentů bylo pozorováno rozpraskání povrchu nádob, silné přepálení nebo začouzení, což by mohlo naznačovat, že k zániku pece mohlo dojít během výpalu. Tento předpoklad by potvrzovala také samotná prrítomnost vsádky v peci, která byla z velké části rozdrcena patrně v souvislosti s destrukcí její klenby.

Co se týče chronologického zařazení souboru, je situace poněkud komplikovanější. Pozornost archeologů se v oblasti jihovýchodní Moravy $\mathrm{v}$ minulosti vztahovala zejména ke studiu velkomoravského osídlení. Přestože zde existuje velké množství středověkých keramických souborů, jejich detailnější vyhodnocení dosud chybí. Při hodnocení keramiky z uherskobrodské pece se tak můžeme opřít o menší vyhodnocené soubory středověké keramiky $\mathrm{z}$ některých okolních lokalit (Uherský Brod - Hradní náměstí, Bartik et al. 2016b; Uherské Hradiště ul. Dlouhá, Bartík et al. 2016c; Velehrad - Schenk et al. 2017) a o obecný model vývoje středověké keramiky. Jedněmi z mála detailněji zkoumaných lokalit v regionu jsou hrad ve Veselí nad Moravou (Plaček - Dejmal 2015), zaniklá vesnice Petrov nedaleko Strážnice (Přibylová 2015) nebo tvrz v Tečovicích u Zlína (Fojtiková 2017). Ve starší literatuře se můžeme setkat pouze se stručnými popisy keramiky, u nichž se ovšem ve velké míře rozchází terminologie a zejména ve tvarech okrajů je jejich použití jako analogií jen velmi omezené. 

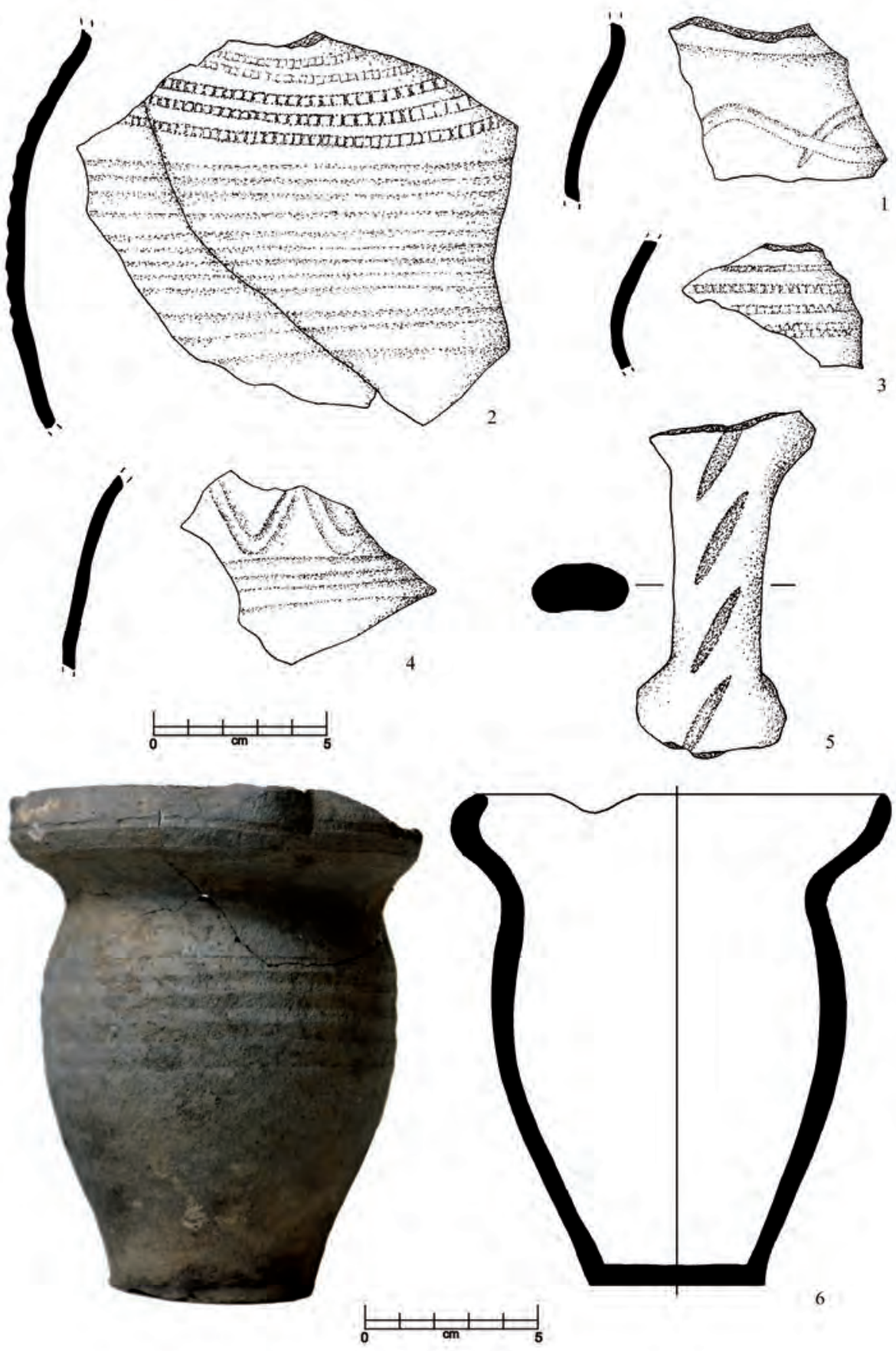

Obr. 9. Výběr keramiky z uherskobrodské pece.

Fig. 9. Selection of pottery from the kiln in Uherský Brod. 
Datace keramiky vychází zejména z tvarové profilace okrajů hrnců, které jsou nejpočetněji zastoupeným typem keramiky s chronologickou citlivostí. Na základě dosud vyhodnocených souborů středověké keramiky lze říci, že na mladohradištní tradici navazují okraje římsovité, které se objevují kolem poloviny 13. století. Na tento typ okraje dále navazuje okruží, ojediněle se vyskytující rovněž už od poloviny 13. století, ale $\mathrm{k}$ jejich hojnějšímu výskytu a unifikaci dochází až ke konci 13. století. Ve 14. století jejich obliba výrazně stoupá a na některých lokalitách tvoří dominantní typ okrajové profilace. Naopak v jiných souborech jsou převažujícím typem seříznuté varianty okrajů, které se objevují v časově souběžných souborech. Seříznuté varianty okraje přežívají do následujícího období, zejména do 1. poloviny 15. století. Ve studovaných souborech z pozdního středověku se lze setkat s okraji přehnutými a ovalenými, které tvoří dominantní složku také v raně novověkých souborech, přičemž jejich chronologická výpovědní hodnota v této době naprosto pozbývá významu. Vzhledem k tomu, že více než polovinu okrajů hrncovitých nádob v analyzovaném souboru z Uherského Brodu je tvořena okružími a další třetinu tvoří seříznuté varianty, je možné uvažovat spíše o mladší dataci (cf. Procházka Peška 2007, 173; Sedláčková 2015, 192; Goš 1977, 293-294; Kouřil - Prix - Wihoda 2002, 267; Prokopová 2016, 166; Blažková 2013, 191-192).

Dalším signifikantním prvkem v této kolekci je vysoký výskyt keramiky zdobené radélkem. Radélková výzdoba je fenomén objevující se v českých zemích převážně v 1. polovině 13. století. Typickým výzdobným prvkem je pak zejména pro oblast střední a jižní Moravy. Její výskyt je však zaznamenán už od konce 12. století, a to především na jihozápadní Moravě. Podíl radélkové výzdoby je značně nevyrovnaný, a zatímco na některých lokalitách tvoří nezanedbatelné množství, jinde se objevuje pouze v ojedinělých kusech. V průběhu 14. století radélková výzdoba ustupuje do pozadí nebo mizí úplně. S počátkem novověku se objevují nové, precizněji zpracované typy radélek, kterým se dostává obliby zejména v Čechách (Unger 1984, 290; Procházka - Peška 2007, 169, 220-221; Nekuda - Reichertová 1968, 117, 122-123, 129-131). Ve sledované oblasti jihovýchodní Moravy se zdá, že radélko zde na některých lokalitách přežívá i přes celé 14. století a pouze postupně dochází k jeho modifikaci do novověké podoby. Přesto však také zde můžeme sledovat nepoměr využití této výzdoby na jednotlivých lokalitách. Ojedinělé zlomky nádob zdobených radélkem jsou zachyceny například ve Veselí nad Moravou, v Petrovicích nebo v Uherském Hradišti na ulici Dlouhá. Větší výskyt byl zaznamenán například v Uherském Hradišti - Otakarově ulici, na Hradním náměstí v Uherském Brodě nebo na hradech Starý Světlov a Engelsberg (Procházka - Sulitková 1984; Kohoutek 1986; Sedláčková 2015; Přibylová 2015; Bartik et al. 2016b, c).

Jediným kompletně dochovaným keramickým tvarem z uherskobrodské pece je pohár se třemi výlevkami, který je charakteristický především pro oblast jižní Moravy. Podobné nálezy pochází například z Brna, Ivančic, Moravského Krumlova, Krnova, zaniklé vsi Teplany u Vranovic, Bystřec, Konůvky a z Melic. Pozoruhodný je nález tohoto typu poháru ve Vídni. Poháry jsou vyrobeny ze zrnitého materiálu s prríměsí slídy a vypálené do šedé, šedočerné až hnědočerné barvy a jejich povrch je obvykle zdoben několika vodorovnými žlábky (obvykle 5). U některých pohárů autoři zmiňují stopy podsýpky na dně nádoby, což by mělo nasvědčovat tvarování obtáčením, některé z nich nesly stopy po odřezání souvisejícím s vytáčením na kruhu. Svojí nálezovou situací odpovídá uherskobrodskému poháru exemplář se třemi výlevkami z Konůvek, který byl objeven nedaleko pece a jež nese stopy špatného výpalu a odříznutí z kruhu, což naznačuje, že byl vyroben technikou vytáčení na kruhu. Datace těchto typů nádob se pohybuje 
v rozmezí 2 . poloviny 14 . až 1 . poloviny 15 . století a je možné, že mohly sloužit k symbolickému přípitku tří osob z jedné nádoby (Unger 1977, 188-194; Šaurová 1979, 66-67; Michna 1974, 66; Kouřil 1981, 358; Měrinský - Unger 1987, 7; Procházka 1994, 327; Belcredi 2006, 330; Vichrová 2009, 42).

Na základě charakteru keramického souboru a několika výše zmíněných chronologicky citlivých prvků a nálezů je možné keramiku a dobu fungování výše popsané pece rámcově datovat do závěru 14. až 1 . poloviny 15 . století. Tuto dataci pak podporuje rovněž stratigrafická situace a superpozice se starším zahloubeným objektem 505. V tomto ohledu je nesmírně cenným vodítkem nález drobné stř́ibrné mince, jež byla objevena v zásypu zmíněného zahloubeného suterénu (obr. 2), ve vrstvě spočívající těsně pod hrnčířskou pecí. Minci se podařilo determinovat jako rokem nedatovaný denárový halér Jošta Moravského (1375-1411), jež byl vyražen $\mathrm{v}$ mincovně Brno a nese iniciály IO a písmena W v úhlech kříže (určení D. Grossmannová, Moravské zemské muzeum Brno). Do výplně zanikajícího objektu 505 se mince dostala s největší pravděpodobností tedy někdy v průběhu poslední třetiny 14. století. Hypotetickou souvislost s výskytem mince bychom mohli najít v písemných pramenech, díky nimž víme, že roku 1392 město Uherský Brod hostilo právě markraběte Jošta. Ten se pak do města vrátil ještě jednou v roce $1394 \mathrm{v}$ souvislosti s jeho tažením proti vpádu Uhrů, vedených Matyášem Konciem (Kučra 1903, 54). Nelze tedy vyloučit, že k výstavbě pece na Komenského ulici došlo až po těchto událostech. Opomenout ovšem nelze ani fakt, že daný typ mince byl v oběhu již dříve a mohl se tak do oblasti JV Moravy dostat jinou formou.

Dalšími otázkami hodnými diskuze jsou poloha hrnčířské pece $\mathrm{v}$ rámci parcelace města a také samotná problematika sociotopografie. Pokud si promítneme zájmovou parcelu na ul.
Komenského do půdorysu středověkého města (obr. 1:A), můžeme vidět, že se nachází na jeho JZ okraji a má přímou vazbu na městské opevnění. To, že byla řemesla pracující s ohněm záměrně umístována $\mathrm{z}$ bezpečnostních důvodů, respektive obav z možného požáru, na okraje měst k hradbám či dokonce za ně do prostoru předměstí, je dnes již obecně uznávaným faktem, opírajícím se o nálezové situace z mnoha středověkých měst. Hrnčířské pece nalezené uvnitř města poblíž hradeb stejně jako v případě Uherského Brodu známe např́klad ještě z Brna či Jihlavy (Nekuda 1963, 57-84; Zatloukal 1998, 27-44; 1999, 60-74). Někdy bývá častější umístění hrnčírú mimo hradby města, spíše než do jejich útrob, spojováno také s jejich celkově špatnou finanční situací (Ostrý 2015, 85). K dokladům středověkého hrnčířství v Uherském Brodě existuje jen velmi málo písemných pramenů, zmiňujících se o tomto řemesle často jen nepřímo nebo v obecné rovině. Stejný problém se týká také dalších řemesel, která jsou často pouze vyjmenována, avšak není uvedena jejich bližší lokalizace. To je i důvod, proč prozatím nemohla být precizněji vypracována sociotopografie řemesel pro Uherský Brod ve vrcholném středověku, stejně jako je tomu např. v Brně nebo Uherském Hradišti (Ostrý 2011; Procházka - Sulitková 1984; Čoupková 2001). Více písemných pramenů se objevuje až od 16. století, a to zejména se zmínkami o sdružování řemeslníků do cechů (Kučera 1903, 94, 182-199). Písemné zprávy hovoří rovněž o čilém obchodním ruchu, kde Uherský Brod vystupuje zejména jako zprostředkovatel mezi českými zeměmi a Uhrami. Některá řemesla se v Uherském Brodě přesto podařilo lokalizovat díky jejich polohopisné tradici, která se odrazila v názvech ulic. Př́́kladem mohou být ulice Tkalcovská a Soukenická v JV části města. Nález pece na městské parcele na křrižovatce ulic Komenského a U Sboru je tak prozatím jediným prokazatelným důkazem pobytu hrnčíře uvnitř městských hradeb. 
Vzhledem k rozsahu archeologického výzkumu jsme pak poněkud limitováni v poznání širších prostorových vztahů. Prozatím se však zdá, že analyzovaná hrnčířská pec nebyla součástí většího výrobního okrsku. Jednalo se spíše o solitérní výrobní objekt nacházející se ve dvorním traktu měštanského domu. Souvislost pece se suterénem domu (obj. 505) nacházejícím se ve středu parcely byla vyloučena stratigrafickou superpozicí obou objektů. Je ovšem možné, že mohla být současná s některým ze suterénů, které byly částečně okryty na východním okraji parcely (obj. 502-504; obr. 1:B), a jež byly lokovány na uliční čáře, $\mathrm{k}$ čemuž docházelo v Uherském Brodě právě v závěru 14. a v průběhu 15. století (analýza keramického materiálu z nich však ještě nebyla dokončena).

\section{Závěr}

Během výzkumu nárožní parcely $\mathrm{v}$ Uherském Brodě na ulici Komenského se kromě množství sídlištních objektů pravěkého, středověkého a novověkého stáří podařilo zdokumentovat část hrnčirrské pece, ze které se dochoval jeden z topných kanálů a část středového soklu se zbytky poslední keramické vsádky. Pece se středovým soklem jsou považovány za přechodný typ mezi pecemi vertikálními a horizontálními a na Moravě se řadí $\mathrm{k}$ nejčastěji se vyskytujícím typům. Topeniště pece se bohužel nepodařilo zachytit $\mathrm{z}$ důvodu jeho narušení mladším novověkým objektem. Získaný archeologický materiál tvořící vsádku pece obsahuje běžné kuchyňské a stolní zboží, přičemž dominantního zastoupení dosahují hrnce. Velká část zlomků náleží okrajovým a horním částem nádob, z če- hož je možné usuzovat, že alespoň spodní patro vsádky bylo tvořeno nádobami otočenými dnem vzhůru. Jedinečným nálezem je pohár se třemi výlevkami, který se dochoval celý. Datace keramiky z pece se opírá o rámcový vývoj keramické středověké produkce, a to zejména z důvodu nedostatečného poznání hrnčirirské výroby na jihovýchodní Moravě. Chronologicky citlivými ukazateli jsou $\mathrm{v}$ tomto prrípadě především okrajové profilace hrnců, které jsou tvořeny převážně okružími a seříznutými (střechovitými) typy. Tyto typy okrajů jsou pro oblast jihovýchodní Moravy poměrně typické a vyskytují se už koncem 13. století, přičemž jejich těžiště spadá do 14. století. Dataci podporuje rovněž již zmíněný pohár se třemi výlevkami, který se objevuje především v jihomoravských souborech z 2. poloviny 14. až 1 . poloviny 15 . století. Keramiku z uherskobrodské pece je tedy možné datovat do poslední třetiny 14. až poloviny 15. století. Zmíněnou dataci podporuje rovněž mince z let 1375-1411 nalezená ve výplni staršího objektu, a to ve vrstvě spočívající těsně pod bází pecí. Vzhledem $\mathrm{k}$ tomu, že část zlomků nesla stopy přepálení, popraskání a deformací, lze usuzovat, že k zániku objektu došlo během výpalu. Prezentovaná pec z Uherského Brodu se zařadila $\mathrm{k}$ nepř́lišs početné skupině pecí lokalizovaných do vnitřního areálu stř̌edověkých měst, jelikož častěji se setkáváme s jejich výskytem spiše za městskými hradbami v prostoru předměstí. Objev a následná analýza nálezové situace i pozůstatků vsádky otevřely nové možnosti studia vrcholně stř̌edověké keramické produkce v Uherském Brodě. Do budoucna bude jistě zajímavá komparace získaných dat s dalšími doposud neanalyzovanými kolekcemi keramiky z archeologicky zkoumaných parcel. 


\section{Bibliografie}

Bartik, J. 2015: Uherský Brod - polyfunkční dům, ulice Komenského/U Sboru. Investorská nálezová zpráva uložená v archivu archeologického oddělení SM v Uherském Hradišti.

Bartik, J. - Chrástek, T. 2016: Uherský Brod (okr. Uherské Hradiště). Přehled výzkumů 57(1), 231.

Bartik, J. - Chrástek, T. - Novotný, J. 2016: Uherský Brod (okr. Uherské Hradiště). Přehled výzkumů 57(2), 319-320.

Bartik, J. - Běhounková, L. - Chrástek, T. - Nohálová, H. - Břečková, K. 2016a: Barokní sklípek se stavební obětinou z archeologického výzkumu na ulici Komenského v Uherském Brodě. Acta musealia muzea jihovýchodní Moravy ve Zlíně a muzea regionu Valašsko XIV, 6-32.

Bartik, J. - Bèhounková, L. - Novotný, J. - Nohálová, H. 2016b: Záchranný archeologický výzkum na Hradním náměstí v Uherském Brodě. Slovácko LVII, 133-149.

Bartik, J. - Chrástek, T. - Běhounková, L. - Rašticová, B. - Nohálová, H. - Novotný, J. - Vavrčík, H. 2016c: Středověké opevnění Uherského Hradiště ve světle archeologického výzkumu v ulici Dlouhá. Slovácko LVII, 79-118.

Belcredi, L. 2006: Bystřec. O založení, životě a zániku středověké vsi. Brno.

Blažková, G. 2013: Vývoj raně novověké kuchyňské a stolní keramiky v Čechách na základě souborů z Pražského hradu. Památky archeologické CIV, 183-230.

Běhounková, L. 2018: Př́spěvek k problematice technologie výroby keramických nádob a její nomenklatury. Studia Archaeologica Brunensia 23, 5-28.

Čoupková, M. (ed.) 2001: Nejstarší uherskohradištská městská kniha. Liber negotinorum civitas Hradisch. Uherské Hradiště.

Fojtiková, H. 2017: Keramický soubor z tvrze Tečovice (okr. Zlín). Bakalářská diplomová práce uložená na Ústavu archeologie a muzeologie Filozofické fakulty Masarykovy univerzity, Brno.

Galuška, L. 2003: Zaniklá hrnčiřská pec středověkého Veligradu-Starého Města - důsledek vpádu Matouše Čáka Třenčanského na Moravu roku 1315? Archaeologia historica 28, 591-609.
Goš, V. 1977: Slovanská keramika 10. - 13. století na severní Moravě. Vlastivědný věstník Moravský XXIX, 291-303.

Chybová, H. 2009: Kroměříz zmizelá a znovu objevená aneb Historie ukrytá pod dlažbou města. Kroměříž.

Kohoutek, J. 1986: Výzkum hradů v oblasti Vizovských vrchů. Archaeologia historica 11, 201-219.

Kouřil, P. 1981: Pohár se třemi výlevkami ze Slezska. Vlastivědný věstník moravský 33, 358.

Kouřil, P. - Prix, D. - Wihoda, M. 2000: Hrady českého Slezska. Brno - Opava.

Kučera, J. 1903: Paměti královského města Uherského Brodu. Brno.

Měřinský, Z. - Unger, J. 1987: Zaniklá ves Koválov u Žabčic. Mikulov.

Michna, P. J. 1974: Archeologické nálezy z výzkumu hradu Melic na Vyškovsku. Vlastivědný věstník moravský XXVI, 61-78.

Mitáček, J. 2011: Historie Hlucka v 10. až 17. století. Od časů Velké Moravy po léta hrůz třicetileté války. In: Mitáček, J. (ed.): Hluk. Dějiny města. Hluk, 103-190.

Nekuda, V. 1963: Nálezy středověkých hrnčiřských pecí na Moravě. Časopis moravského muzea v Brně XLVIII, 57-84.

Nekuda, V. - Reichertová, K. 1968: Středověká keramika v Čechách a na Moravě. Brno.

Ostrý, C. 2011: Sociotopografie města Brna ve 14. století. Bakalářská diplomová práce uložená na Historickém ústavu Filozofické fakulty Masarykovy univerzity. Brno.

Ostrý, C. 2015: Projevy řemeslné činnosti v archeologických situacích v jádrech vybraných měst na Moravě ve středověku. Bakalářská diplomová práce uložená na Ústavu archeologie a muzeologie Filozofické fakulty Masarykovy univerzity. Brno.

Pavelčik, J. 1995: Uherský Brod - ul. B. Němcové. NZ č. j. 10/95 uložená v archivu archeologického oddělení Slováckého muzea v Uherském Hradišti.

Plaček, M. - Dejmal, M. 2015: Veselí nad Moravou: středověký hrad v říční nivě. Brno.

Procházka, R. 1984: Předběžná zpráva o archeologickém výzkumu v Uherském Brodě v roce 1982. Studia comeniana et historica 28, 147-149.

Procházka, R. 1994: Brněnská stolní a kuchyňská keramika 2. poloviny 14.-poč. 15. století. Pravěk Nová řada, 323-344. 
Procházka, R. 2015: Mittelalterliche Töpferöfen in Mähren. In: Lutz Grunwald (Hrsg.), Den Töpfern auf der Spur. Orte der Keramikherstellung im Licht der neuesten Forschung. Mainz, 215-224.

Procházka, R. - Peška, M. 2007: Základní rysy vývoje brněnské keramiky ve 12.-13./14. století. Přehled výzkumů 48, 143-270.

Procházka, R. - Sulitková, L. 1984: Uherské Hradiště ve 13.-15. století: sociálněekonomická struktura, topografie. Uherské Hradiště.

Prokopová, L. 2016: Vypovídací hodnota archeologických pramenů z odpadní jímky v Orlí 19/21 v kontextu středověkého Brna. Magisterská diplomová práce na Ústavu archeologie a muzeologie Filozofické fakulty Masarykovy univerzity. Brno.

Přibylová, M. 2015: Zaniklá středověká osada v katastru obce Petrov v kontextu osídlení strážnického Pomoraví. Magisterská diplomová práce uložená na Ústavu archeologie a muzeologie Filozofické fakulty Masarykovy univerzity. Brno.

Sedláčková, L. 2015: Středověká keramika. In: Plaček, M. - Dejmal, M. (eds.): Veselí nad Moravou: středověký hrad v říční nivě. Brno, 188-217.

Shenk, Z. - Běhounková, L. - Chrástek, T. - Janiš, D. Mikulik, J. - Vrla, R. 2016: Př́spěvek k problematice opevnění v poloze „Dolní a Horní Hrádek“ na katastrálním území Velehradu. Slovácko LVIII, 131-155.

Snášil, R. 1979: Záchranný výzkum středověkého Starého Města v poloze „Za zahradou“, k. o. Uherské Hradiště. Archaeologia historica 4, 73-75.

Snášil, R. 1982a: Keramický depot z počátku 14. století z Uherského Hradiště - Starého Města. Přehled výzkumů 1980, 44-46.

Snášil, R. 1982b: Hrnčířská pec z trhové vsi Veligradu. Zkoumání výrobních objektů archeologickými metodami. Sborník ze semináře 1979, 3-24.

Snášil, R. 1983: Př́nos archeologických dokladů specializovaných řemesel pro poznání ekonomiky
Uherskohradištska za feudalismu. Archaeologia historica 8, 95-107.

Šaurová, D. 1979: Pohár se třemi výlevkami z hrnčîrské dílny v Konůvkách. Vlastivědný věstník moravský XXXI, 66-67.

Thér, R. 2009: Technologie výpalu keramiky a její vztah k organizaci a specializaci ve výrobě keramiky v kontextu kultur popelnicových polí. Disertační práce na Ústavu antropologie Přrírodovědecké fakulty Masarykovy univerzity. Brno.

Tomeček, R. 2002: Uherský Brod. Putování historií královského města. Uherský Brod.

Unger, J. 1977: Př́íspěvek k datování a rozšíření středověkých pohárů se třemi výlevkami na jižní Moravě. Vlastivědný věstník moravský 29, 188-194.

Unger, J. 1984: Základní horizonty keramiky 12.-15. století na soutoku Jihlavy a Svratky. Archeologické rozhledy XXXVI, 288-296.

Varadzin, L. 2010: Hrnčířská výroba ve východní část střední Evropy 6.-13. století v archeologických pramenech. Archeologické rozhledy LXII, 17-71.

Vichrová, Š. 2009: Odraz hmotné kultury v archeologických pramenech na př́kladu obj. č. 638 z poloviny 15. století z Dominikánské ulice v Brně. Bakalářská diplomová práce na Ústavu archeologie a muzeologie Filozofické fakulty Masarykovy univerzity. Brno.

Zatloukal, R. 1998: Středověké hrnčířské pece z Jihlavy a okolí. Vlastivědný sborník vysočiny XI, 27-44.

Zatloukal, R. 1999: Archeologické doklady hrnčiřství ve 13 . až polovině 16 . století. Archaeologia technica $11,60-74$.

Zemek, M. (eds.) 1972: Uherský Brod: minulost i současnost slováckého města. Brno.

\section{Elektronické zdroje:}

http://www.geology.cz 


\section{Medieval pottery kiln from Uherský Brod - Komenského Street}

A 2015 archaeological rescue excavation at the crossing of Komenského and U Sboru streets in Uherský Brod (Fig. 1) has explored one part of an original urban plot adjacent to the town wall. In this area, traces of bronze age, high medieval and modern settlement were documented.

Feature 509, which is treated in this article, was situated in the central part of the examined plot, in a double superposition with other structures. The bottom of the feature was recessed into an older medieval house basement. The western part was disturbed by a modern structure after the original feature was abandoned. The southern part of the feature was damaged during preparatory construction works before the excavation has begun (Fig. 2). Despite heavy damage, the find context was interpreted as a pottery kiln, which is indicated by the spatial form, strongly charred walls and a crushed ceramic charge inside the feature.

Preserved is major part of one stoking channel, the central support, originally probably lined with flat stones, the wall foundations and the construction pit. The dimensions of the kiln are $252 \mathrm{~cm}$ in length and $93 \mathrm{~cm}$ in width. The original length can be estimated to as much as $3 \mathrm{~m}$ and width to $180 \mathrm{~cm}$ (Fig. 4).

Regarding the preserved parts we can suppose that the examined relic belongs to vertical kilns with central floor support. This kiln type appears to be dominant in Moravia and its occurrence is dated to the 13th - 15th/16th centuries (Procházka 2015, 217219; Nekuda - Reichertová 1968, 40-48; Thér 2009, 92-93; Varadzin 2010, 27-28).

The ceramic collection discovered inside the kiln comprises 1174 fragments, from which 362 individuals were singled out. The collection mostly contains unspecifiable belly fragments. Detected were pots, handled pots, bell-shaped lids, jugs, bowls, a beaker and a conical lid. Vessels are mostly represented by belly and rim fragments. One vessel in the form of a three-spouted beaker is completely preserved (Fig. 9:6), in one case the mending of fragments enabled to reconstruct the upper part of a small pot (Fig. $8: 8)$. Jug rims are mostly plain, plain flaring, or collared (Fig. 6:39-45). Pot rims are collared (Fig. 5), bevelled or rounded (Fig. 6:1-19), sporadically also plain, plain flaring or thickened (Fig. 6:24-27), everted (Fig. 6:20-23), raised (Fig. 6:31-33), cornice-shaped (Fig. 6:28, 29), widened profiled (Fig. 6:30) and planed (Fig. 6:34). Bowls have simple, widened, variously bevelled rims (Fig. 6:35-38). Lid rims are bilaterally widened (Fig. 6:51-54). Bell-shaped lids have internally thickened and in-turned (Fig. 6:46-48), internally thickened (Fig. 6:49-50) and sporadically also out-turned (Fig. 6:55) rims. Most fragments were made from a fabric without graphite and mica admixture, with fine-grained temper, and were fired in a reducing atmosphere with medium to low temper content. Several fragments exhibited traces of possible secondary oxidation firing. Less frequent is non-graphite pottery with small admixture of mica and fine-grained temper, fired in a reducing atmosphere. The fabric without admixtures, with low to medium content of fine-grained temper, fired in oxidising atmosphere, is represented by a few fragments. Isolated occurrence was detected with fragments made from a fabric without admixtures, with medium-grained temper, fired in a reducing atmosphere, or from a non-graphite fabric with small admixture of mica and with powdery to fine-grained temper, fired in oxidising atmosphere with a secondary reduction firing. The colour of ceramic fragments is mostly medium to dark grey and brown-grey, mostly in combination with a brighter-coloured core. Ceramic vessels were mostly made by wheel-throwing, a technique where a lump of clay was placed centrally on the potter's wheel and then shaped as the wheel turned. Sporadically also coiling was applied, where clay was rolled into long threads, which were then pinched and smoothed together on a slow wheel (tournette) to form the body of a vessel (Běhounková 2018, 1314). Decoration occurs in more than one-half of all examined individuals. Most frequent are incised lines (Fig. 7:11; Fig. 9:6), circumferential helical bulge (Fig. 7:15), helical groove (Fig. 7:3) and simple or double wave (Fig. 7:5, 7; Fig. 8:3; Fig. 9:1). Another types of decoration, such as bands of roller squares (Fig. 7:8, 9, 14; Fig. 8:7; Fig. 9:3), roller triangles (Fig. 7:2, 6, 10; Fig. 8:5), multiple stepped helix, roller rectangles 
or trapeziums, combination of waves and incised lines (Fig. 8:4; Fig. 9:4), multiple indentations on the handle (Fig. 9:5), combination of roller squares and incised lines (Fig. 8:2, 9; Fig. 9:2) or a raised cordon of triangular cross-section, are less frequent. Other types of decoration occur only sporadically (Fig. 7:1, 4, 12, 13; Fig. 8:1, 6, 8).

With regard to the large amount of preserved rims and lips we can suppose that the lower part of the kiln charge consisted of vessels turned bottom up. The kiln was probably destroyed during the last fi- ring procedure, which is indicated by overfired, sooted and deformed ceramic fragments.

On the basis of chronologically sensitive elements on pottery, such as rim profiles, roller decoration patterns or occurrence of three-spouted beakers, the feature can be dated back to the end of the 14th or to the first half of the 15th century. This chronological position is also supported by the stratigraphic situation on site. Moreover, a valuable clue is provided by a silver Heller of Jobst of Moravia (1375-1411), which was found in the infill of a feature immediately below the kiln.

\section{Mgr. Lenka Bartíková}

- Ústav archeologie a muzeologie, Filozofická fakulta, Masarykova univerzita, A. Nováka 1, 60200 Brno, Česká republika behounkovalenka@gmail.com

\section{Mgr. Jaroslav Bartík}

- Slovácké muzeum v Uherském Hradišti Štefánikova 1285, 68601 Uherské Hradiště, Česká republika adraj.bartik@gmail.com 